\title{
UJI EFEKTIVITAS ANTI BAKTERI EKSTRAK BIJI PEPAYA (Carica papaya L.) TERHADAP KELANGSUNGAN HIDUP IKAN NILA (Oreochromis niloticus) PASCA INFEKSI Aeromonas hydrophila
}

\section{TEST THE ANTI-BACTERIAL EFFECTIVENESS OF PAPAYA SEED EXTRACT (Carica papaya L.) AGAINST SURVIVAL TILAPIA (Oreochromis niloticus) POST- INFECTION Aeromonas hydrophila}

\author{
Kherma Levia $\left.^{1 *}\right)$, Saptono Waspodo ${ }^{1)}$, Baiq Hilda Astriana ${ }^{1}$ \\ ${ }^{1)}$ Program Studi Budidaya Perairan Jurusan Perikanan dan Ilmu Kelautan \\ Universitas Mataram \\ *alamat korespondensi: herma15mei@gmail.com
}

\begin{abstract}
Abstrak
Maraknya budidaya ikan nila ini tidak bisa menghindari penerapan intensifikasi budidaya yang tinggi. Hal ini dapat memberikan dampak negatif, salah satunya timbulnya penyakit Motile Aeromonas Septicaemia (MAS). Motile Aeromonas Septicaemia (MAS) merupakan salah satu penyakit yang dapat menyerang ikan nila, penyakit ini disebabkan oleh bakteri Aeromonas hydrophyla. Penelitian ini bertujuan untuk mengetahui pengaruh penggunaan ekstrak biji pepaya (Carica papaya L.) terhadap kelangsungan hidup ikan nila, pertumbuhan ikan nila dan profil sel darah merah ikan nila yang terinfeksi bakteri A. hydrophila. Metode penelitian yang digunakan adalah metode eksperimental dengan ancangan Acak Lengkap (RAL) adapun perlakuannya yaitu P1 (perendaman dengan konsentrasi 20\%), P2 (30\%), P3 (40\%), P4 (50\%) dilakukan selama 30 hari. Hasil penelitian menunjukkan kelangsungan hidup tertinggi yaitu pada perlakuan P3 yaitu $66,66 \%$ dan terendah yaitu P0 yaitu 13,33\%, Hasil uji darah merah menunjukkan darah ikan sehat rata-rata diatas $30 \times 10^{5} \mathrm{sel} / \mathrm{mm}^{3}$ sedangkan ikan sakit ikan yang telah diinfeksi bakteri $A$. hydrophila menunjukka ratarata diatas $5 \times 10^{5} \mathrm{sel} / \mathrm{mm}^{3}$ dan ikan pada perlakuan P1, P2, P3, dan P4 yang telah direndam menggunakan ekstrak biji pepaya dan di pelihara selama 14 hari menujukkan hasil uji darah diatas $25 \times 10^{5} \mathrm{sel} / \mathrm{mm}^{3}$ sedangkan ikan yang tidak direndam menunjukkan hasil perhitungan yaitu $17,4 \times 10^{5} \mathrm{sel} / \mathrm{mm}^{3}$. Kesimpulan dari penelitian ini yakni perlakuan P2 dengan dosis $30 \%$ direkomendasikan untuk tingkat kelangsungan hidup ikan nila. P1 dengan dosis $20 \%$ dengan pemberian ekstrak biji pepaya berpengaruh nyata terhadap jumlah sel darah merah ikan nila. Sedangkan untuk pertumbuhan panjang mutlak dan berat mutlak ikan nila, perendaman ekstrak biji pepaya tidak memberikan pengaruh nyata.

Kata Kunci : Ikan Nila, Aeromonas hydrophila, dan Ekstrak Biji Pepaya.
\end{abstract}

\begin{abstract}
The rise of tilapia fish cultivation cannot avoid the application of high cultivation intensification. This can have a negative impact, one of which was the onset of Motile Aeromonas Septicaemia (MAS). Motile Aeromonas Septicaemia (MAS) was one of the diseases that can attack tilapia, this disease was caused by the bacterium Aeromonas
\end{abstract}


hydrophyla. The study aimed to determine the effect of the use of pepaya seed extract (Carica papaya L.) on the survival of tilapia fish, tilapia growth and the profile of red blood cells of tilapia fish infected with A. hydrophila bacteria. The research method used was an experimental method with a completely randomized design (CRD) while the treatments are P1 (immersion with a concentration of 20\%), P2 (30\%), P3 (40\%), P4 (50\%) carried out for 30 days. The results showed the highest survival in the P3 treatment which is $66.66 \%$ and the lowest is $\mathrm{P} 0$ which is $13.33 \%$, red blood test results show healthy fish blood on average above $30 \times 10^{5}$ cells $/ \mathrm{mm}^{3}$ while sick fish that have been infected with $A$. hydrophila bacteria point to an average of above $5 \times 10^{5}$ cells $/ \mathrm{mm}^{3}$ and fish in the treatment of P1, P2, P3, and P4 that have been soaked using pepaya seed extract and maintained for 14 days show blood test results above $25 \times 10^{5}$ cells $/ \mathrm{mm}^{3}$ while fish that are not soaked show the results of calculations of $17.4 \times 10^{5}$ cells $/ \mathrm{mm}^{3}$. The conclusion of this study was that P2 treatment with a dose of $30 \%$ was recommended for the survival rate of tilapia fish. P1 with a dose of $20 \%$ with the administration of pepaya seed extract has a real effect on the number of red blood cells of tilapia fish. As for the absolute long growth and absolute weight of tilapia fish, the immersion of pepaya seed extract has no real effect.

Keywords: Tilapia, Aeromonas hydrophila, and Pepaya Seed Extract.

\section{PENDAHULUAN}

\section{Latar Belakang}

Ikan nila (Oreochromis niloticus) adalah ikan tilapia yang berjenis ikan air tawar introduksi yang mempunyai nilai ekonomis cukup tinggi di daerah Asia termasuk di Indonesia, ikan nila didatangkan ke Indonesia pada tahun 1969. Semenjak datang ke Indonesia, ikan nila mulai dibudidayakan dan mengalami perkembangan yang sangat pesat dan memiliki peminat yang cukup tinggi. Hal ini sesuai dengan pendapat Sari (2012), yang menyatakan bahwa perkembangan budidaya ikan nila sebagai salah satu komoditas perikanan air tawar mulai menjadi kegiatan agribisnis yang cukup menjanjikan, sehingga pada tahun 1990an kesadaran akan perkembangan budidaya ikan nila ini mulai disadari dan digarap dengan baik. Semenjak saat itu, ikan nila mulai diperkenalkan kepada masyarakat untuk dibudidayakan.

Ikan nila merupakan ikan yang mampu beradaptasi dengan baik di berbagai lingkungan. Selain beradaptasi dengan baik ikan nila juga dapat dipijahkan dengan mudah dan memiliki pertumbuhan yang sangat cepat, sehingga hal ini dapat mendukung masyarakat dalam membudidayakannya. Menurut Lasena et al. (2016), Kementrian Kelautan dan Perikanan mentargetkan produksi ikan ini mencapai 1,25 juta ton pada tahun 2014. Maraknya budidaya ikan nila ini tidak bisa menghindari penerapan intensifikasi budidaya yang tinggi. Intensifikasi ini dapat memberikan dampak negatif, salah satu dampak negatif yang dapat ditimbulkan yaitu adanya penyakit yang dapat menyerang ikan nila. Motile Aeromonas Septicaemia (MAS) merupakan salah satu penyakit yang dapat menyerang ikan nila, penyakit ini disebabkan oleh bakteri Aeromonas hydrophyla (Sari et al., 2017).

Aeromonas hydrophyla dikenal di Indonesia sejak tahun 1980. Menurut Sari et al. (2017), A. hydrophila merupakan bakteri normal yang berada di perairan air tawar. Perubahan kondisi lingkungan perairan dapat menyebabkan bakteri menjadi bersifat pathogen. Dengan padat penebaran ikan yang tinggi dapat mengakibatkan 
bakteri menyebar dengan cepat dan kematian benih yang tinggi juga tidak dapat dihindarkan. Salah satu penyebab penyebaran bakteri ini adalah dengan adanya kontak langsung antara ikan yang sehat dan ikan yang terinfeksi. Infeksi A. hydrophila juga dapat berasal dari air tempat pemeliharaan ikan yang terinfeksi.

Antibiotik atau zat kimia merupakan bahan yang sering dipergunakan untuk menanggulangi penyakit pada budidaya ikan. Menurut sumaryati (2008) dalam Sari et al. (2017) dalam proses pengobatan penggunaan antibiotik dalam jangka waktu yang cukup lama dapat mengakibatkan bakteri resisten, selain itu antibiotik memiliki harga yang cukup mahal dan juga dapat mencemari lingkungan. Antibiotik diberikan dengan beberapa cara antara lain dengan mencampurkan kedalam pakan, perendaman ikan, dan penyuntikan, sehingga ampas atau sisa antibiotik dapat berperan sebagai kontaminan dalam suatu proses kimia tertentu bagi ikan yang dipelihara. Upaya lain yang dilakukan untuk mengobati penyakit ini adalah dengan menggunakan bahan alami. Salah satu bahan alami yang mengandung senyawa antibakteri adalah biji pepaya.

Pepaya merupakan salah satu buah yang banyak tumbuh dengan mudah di Indonesia, sehingga pepaya mudah dijumpai di berbagai pelosok Indonesia. Semua bagian pepaya dapat dimanfaatkan termasuk bijinya. Di Indonesia pemanfaatan biji pepaya sangat kurang, biji pepaya hanya dipergunakan untuk ditanam kembali. Menurut Ristianti et al. (2015), biji pepaya mengandung senyawa bersifat antimikroba. Selain mengandung asamasam lemak, biji pepaya juga mengandung metabolit sekunder seperti golongan fenol, terpenoid, alkaloid, dan saponin. Golongan triterpenoid merupakan komponen utama dari biji pepaya dan memiliki aktifitas fisiologi sebagai antibakteri.

Penelitian sebelumnya yang telah dilakukan oleh Jaipah et al. (2017) menunjukkan efek antibakteri biji pepaya terhadap pertumbuhan beberapa bakteri seperti Escherichia coli, Staphylococcus aureus, Pseudomonas aeruginosa, Salmonella typhi. Penelitian mengenai efektivitas ekstrak biji pepaya terhadap kelangsungan hidup ikan nila yang terinfeksi bakteri A. hydrophila belum dilakukan sejauh ini. Dengan demikian perlu dilakukan pengujian efektivitas ekstrak biji pepaya terhadap ikan nila yang terinfeksi bakteri $A$. hydrophila. Adapun tujuan dilakukannya penelitian ini yaitu untuk mengetahui pengaruh penggunaan ekstrak biji pepaya (Carica papaya) terhadap kelangsungan hidup ikan nila, pertumbuhan ikan nila dan profil sel darah merah ikan nila yang terinfeksi bakteri A. hydrophila.

\section{METODE PENELITIAN Waktu dan Tempat}

Penelitian ini telah dilaksanakan selama 30 hari, dimulai tanggal 21 September 2020- 20 Oktober 2020. Tempat penelitian yaitu di Laboratorium Mikrobiologi Pertanian dan Laboratorium Budidaya Perairan, Fakultas Pertanian Universitas Mataram dan Laboratorium MIPA UNRAM.

\section{Alat dan Bahan}

Alat-alat yang digunakan pada penelitian ini antara lain yakni mikro pipet, bunsen, ose, pawan petri, penggaris, aerator, akuarium, timbangan analitik, $\mathrm{pH}$ meter, DO meter, Thermometer, alat tulis, saringan, autoklaf, haemocytometer. Sedangkan bahan-bahan yang digunakan antara lain ikan nila, air tawar, pakan pellet, ekstrak biji pepaya, bakteri Aeromonas 
hydrophila, alkohol, korek api, kertas label, tissue, etanol, sabun.

\section{Rancangan Penelitian}

Rancangan percobaan yang digunakan dalam penelitian ini adalah Rancangan Acak Lengkap (RAL) dengan 5 perlakuan dan 3 kali ulangan, sehingga diperoleh 15 unit percobaan. Adapun konsentrasi ekstrak biji pepaya yang digunakan pada percobaan ini mengacu pada percobaan sebelumnya yang dilakukan oleh Jaipah et al. (2017) tentang uji efektifitas antibakteri biji pepaya terhadap pertumbuhan bakteri Escherichia coli secara in vitro, dimana pada penelitian ini menggunakan ekstrak dengan konsentrasi 20\%, 30\%, $40 \%$ dan $50 \%$, sehingga perlu dilakukan percobaan perendaman bakteri $A$. hydrophila dengan konsentrasi yang sama, adapun perlakuannya yaitu:

Perlakuan $=$ Ikan diinfeksi bakteri $0 \quad$ A. hydrophila tidak dilakukan perendaman dengan ekstrak biji pepaya

Perlakuan $=$ Perendaman dengan $1 \quad$ konsentrasi $20 \%$

Perlakuan $=$ Perendaman dengan

$2 \quad$ konsentrasi $30 \%$

Perlakuan $=$ Perendaman dengan $3 \quad$ konsentrasi $40 \%$

Perlakuan $=$ Perendaman dengan $4 \quad$ konsentrasi $50 \%$

\section{Prosedur Penelitian}

\section{Persiapan Wadah dan Bahan Uji}

Wadah pemeliharaan yang digunakan adalah berupa akuarium sebanyak 15 unit dengan ukuran wadah pemeliharaan $40 \times 40 \times 60 \mathrm{~cm}^{3}$ diisi air sebanyak 30 liter dengan padat tebar untuk masing-masing wadah 10 ekor ikan uji dengan ukuran $8 \mathrm{~cm}$ dan bobot berat 5-10 gram, benih yang digunakan didapatkan dari Balai Benih Ikan Batu Kumbung, Narmada, Lombok Barat. Sedangkan wadah perendaman digunakan akuarium berkapasitas 1 liter. Sebelum digunakan wadah dicuci menggunakan sabun (sunlight) dan dibilas dengan air tawar kemudian didiamkan selama 24 jam sebelum wadah digunakan. Selain persiapan wadah dilakukan persiapan bahan uji seperti pembuatan ekstrak biji pepaya yang dilakukan di Laboratorium MIPA UNRAM dan persiapan ikan yang akan diuji.

\section{Pembuatan Kultur Bakteri}

Pembuatan kultur bakteri ini bertujuan untuk memperbanyak bakteri yang didapatkan dari Laboratorium Mikrobiologi BBPBAP Jepara. Bakteri yang didapat kemudian dikultur diatas media agar yang kemudian diingkubasi selama 24 jam, pengkulturan bakteri dilakukan di Laboratorium Mikrobiologi Pertanian, UNRAM. Pembuatan kultur bakteri A. hydrophila dilakukan dengan cara menginokulasikan ose biakan murni bakteri keatas media agar kemudian diinkubasi selama 24 jam dengan suhu inkubator $37^{\circ} \mathrm{C}$. Bakteri yang disuntikkan pada ikan uji mengacu pada penelitian sebelumnya yang dilakukan oleh Jaipah (2017) bahwa bakteri yang disuntikkan sebesar $10^{6} \mathrm{CFU} / \mathrm{ml}$.

\section{Pembuatan Ekstrak Biji Pepaya}

Pembuatan ekstrak biji pepaya dilakukan di Laboratorium MIPA, UNRAM. Biji pepaya dikeringkan terlebih dahulu kemudian pembuatan ekstrak biji pepaya dilakukan dengan metode maserasi menggunakan pelarut etanol 96\%. Hasil dari ekstraksi dengan konsentrasi $100 \%$ kemudian diencerkan menggunakan aquades hingga menghasilkan ekstrak dengan konsentrasi 20\%, 30\%, 40\%, dan 50\% (Paramesti, 2014) dengan perhitungan disajikan menggunakan rumus sebagai berikut :

$\mathrm{M} 1 \mathrm{xV} 1=\mathrm{M} 2 \mathrm{xV} 2$ 
M1 : konsentrasi ekstrak biji pepaya yang tersedia $(\%)$

M2 : konsentras ekstrak biji pepaya yang akan dibuat (\%)

V1 :volume larutan yang akan diencerkan $(\mathrm{ml})$

V2 : volume larutan ( air+ekstrak) yang diinginkan $(\mathrm{ml})$

Adapun prosedur pembuatan larutan uji ini yaitu dari $200 \mathrm{ml}$ ekstrak murni yang didapatkan dibagi menjadi 8 dikarenakan dilakukan $2 \mathrm{x}$ perendaman ikan sakit pada 4 perlakuan sehingga diperoleh dosis untuk masing-masing perlakuan yaitu $25 \mathrm{ml}$, adapun prosedur yang dilakukan yaitu sebagai berikut :

Pembuatan perlakuan 1 dengan dosis $20 \%$ yaitu dengan cara mencampurkan $25 \mathrm{ml}$ ekstrak murni ke dalam $100 \mathrm{ml}$ aquades.

Pembuatan perlakuan 2 dengan dosis $30 \%$ yaitu dengan cara mencampurkan $25 \mathrm{ml}$ ekstrak murni ke dalam 58,33 ml aquades.

Pembuatan perlakuan 3 dengan dosis $40 \%$ yaitu dengan cara mencampurkan $25 \mathrm{ml}$ ekstrak murni ke dalam 37,5 ml aquades.

Pembuatan perlakuan 4 dengan dosis $20 \%$ yaitu dengan cara mencampurkan $25 \mathrm{ml}$ ekstrak murni ke dalam $25 \mathrm{ml}$ aquades.

\section{Aklimatisasi Ikan}

Ikan nila yang akan digunakan dalam penelitian ini terlebih dahulu diaklimatisasi dalam akuarium pemeliharaan. Ikan diberikan pakan dua kali sehari sebanyak 5\% dari biomasa. Aklimatisasi dilakukan selama 24 jam sebelum diberikan perlakuan agar ikan tidak stres.

\section{Perlakuan}

Prosedur penelitian pemanfaatan biji pepaya untuk mencegah infeksi bakteri $A$. hydrophila pada ikan nila dimulai dengan penginfeksian bakteri $A$. hydrophila pada ikan nila, penginfeksian dilakukan dengan cara bakteri A. hydrophila disuntikkan menggunakan dosis $0,1 \mathrm{~mL}$ per ekor. Lama waktu penginfeksian yaitu 48 jam atau setelah ikan menunjukkan gejala klinis seperti pendarahan pada pangkal sirip, ikan memproduksi lendir berlebihan dan adanya ulcer pada bagian bekas penginfeksian. Setelah adanya tanda-tanda ikan terinfeksi, dilakukan uji darah pertama untuk mengetahui ikan benar-benar terinfeksi bakteri A. hydrophila. Setelah ikan dinyatakan terinfeksi bakteri $A$. hydrophila, dilakukan perendaman menggunakan ekstrak biji pepaya dengan konsentrasi perendaman yaitu perlakuan ke-1 $20 \%$, perlakuan ke-2 $30 \%$, perlakuan ke-3 $40 \%$, dan perlakuan ke-4 50\%, sedangkan perlakuan ke-0tidak di berikan pengobatan atau perlakuan. Proses perendaman dilakukan 2 kali selama 5 menit dengan selang waktu 24 jam dan waktu perendaman tidak ditentunkan hal ini mengacu pada penelitian sebelumnya yang dilakuan oleh Rini Mastuti (2017) bahwa lama perendaman ikan nila yang terinfeksi bakteri $A$. hydrophilamenggunakan ekstrak daun mangrove jenis Rhizophora sp. yaitu $2 \mathrm{x}$ perendaman dengan lama perendaman 5 menit dan selang waktu 24 jam, sehingga perlu dilakukan percobaan perendaman pada ikan nila yang terinfeksi $A$. hydrophila dengan waktu perendaman yang sama tetapi ekstrak yang berbeda. Setelah dilakukan perendaman, ikan dikembalikan kedalam akuarium untuk dilakukan pengamatan pada pemulihan ikan selama 14 hari. Selama masa pemulihan ikan diberi makan $2 \mathrm{x}$ sehari yaitu pagi dan sore hari. Setelah masa pemeliharaan, dilakukan uji darah ke-3 untuk memastikan bahwa tidak ada lagi bakteri $A$. hydrophila yang tumbuh pada tubuh ikan. 
Parameter yang Diamati

Persentase Kelangsungan Hidup (SR)

Persentase kelangsungan hidup

ikan cupang dapat dihitung dengan persamaan (Effendi, 1979 dalam Arifin, 2016):

$$
\mathrm{SR}=\frac{\text { jumlah ikan yang dipanen (ekor) }}{\text { jumlah ikan yang di tebar (ekor) }} \times 100 \%
$$

Keterangan:

SR : Kelangsungan hidup (Survival rate) $(\%)$

$\mathrm{Nt}$ : Jumlah ikan pada akhir pemeliharaan (ekor)

N0 : Jumlah ikan pada awal pemeliharaan (ekor)

\section{Parameter Uji Sel Darah Merah}

Pengambilan darah ikan uji dilakukan sebanyak tiga kali, yaitu pada ikan normal sebelum diberi perlakuan, pengambilan darah kedua setelah ikan menunjukkan gejala klinis terserang $A$. hydrophila, dan yang ketiga pada hari ke-14 pasca pengobatan, darah diambil dari 3 ekor ikan uji dari setiap perlakuan.

Parameter pendukung uji darah meliputi jumlah total eritrosit dan morfologi eritrosit. Jumlah total eritrosit dihitung sebanyak 5 kotak kecil pada haemocytometer dengan rumus (Blaxhall dan Daisley, 1973 dalamMastuti, 2017) :

Jumlah eritrosit $=\Sigma \mathrm{N} \mathrm{X} 10^{4} \mathrm{sel} / \mathrm{mm}^{3}$

Keterangan:

$\mathrm{N}$ = Jumlah eritrosit yang terhitung dalam 5 lapangan pandang

$10^{4}$ = faktor pengenceran

Prosedur perhitungan jumlah sel darah merah diukur menurut Blaxhall dan Daisley (1973), pertama darah dihisap dengan pipet yang berisi bulir pengaduk warna merah sampai skala 1 (pipet untuk mengukur jumlah sel darah merah), lalu tambahkan larutan
Hayem's sampai skala 101, pengadukan darah di dalan pipet dilakukan dengan mengayunkan tangan yang memegang pipet seperti membentuk angka delapan selama 3-5 menit sehingga darah tercampur rata. Dua tetes pertama larutan darah dalam pipet dibuang, selanjutnya teteskan pada haemocytometer tipe Neubauer dan tutup dengan gelas penutup. Kemudian, hitung jumlah sel darah merah dengan bantuan mikroskop dengan pembesaran $400 \mathrm{x}$.

Pengamatan morfologi eritrosit dilakukan dengan cara mengamati bentuk sel darah merah dengan menggunakan mikroskop dengan perbesaran 10 x 100. Data morfologi eritrosit yang diperoleh, dilihat perubahannya dan dibandingkan antara kelompok kontrol dengan perlakuan.

\section{Pertumbuhan Berat Mutlak dan Panjang Mutlak}

Pertumbuhan berat mutlak ikan nila ini di hitung dengan menggunakan rumus Effendi (1979) dalam Mulqan (2017), yaitu:

$\mathrm{W}=\mathrm{Wt}-\mathrm{Wo}_{\mathrm{o}}$

Keterangan:

$\mathrm{W}=$ pertumbuhan mutlak $(\mathrm{g})$

$\mathrm{Wt}=$ bobot akhir

Wo $=$ bobot awal $(\mathrm{g})$

Sedangkan Pertambahan panjang mutlak dihitung dengan menggunakan rumus Effendie (1997) dalam Mulqan (2017):

$\mathrm{Pm}=\mathrm{Lt}-\mathrm{Lo}$

$\mathrm{Pm}=$ Pertambahan panjang mutlak (cm)

$\mathrm{Lt}=$ Panjang rata-rata akhir $(\mathrm{cm})$

Lo $=$ Panjang rata-rata awal $(\mathrm{cm})$.

\section{Kualitas Air}

Kualitas air yang telah diukur dalam penelitian ini adalah suhu, derajat keasaman $(\mathrm{pH})$, amoniak, dan oksigen terlarut (Disolved Oxygen). Pengukuran 
parameter tersebut dilakukan pada awal, tengan dan akhir pemeliharaan.

\section{Analisis Data}

Data yang telah diperoleh berupa kelangsungan hidup ikan uji yang dianalisis menggunakan analisis sidik ragam (Anova) dengan tingkat kepercayaan 95\%.Data yang menunjukkan berpengaruh nyata maka dilakukan uji lanjut (BNT). Data kualitas air dan hasil uji darah yang meliputi totaleritrositdianalisis secara deskriptif.

\section{HASIL}

\section{Tingkat Kelangsungan Hidup Ikan Nila}

Tingkat kelangsungan hidup ikan nila dapat dilihat pada gambar 1 .

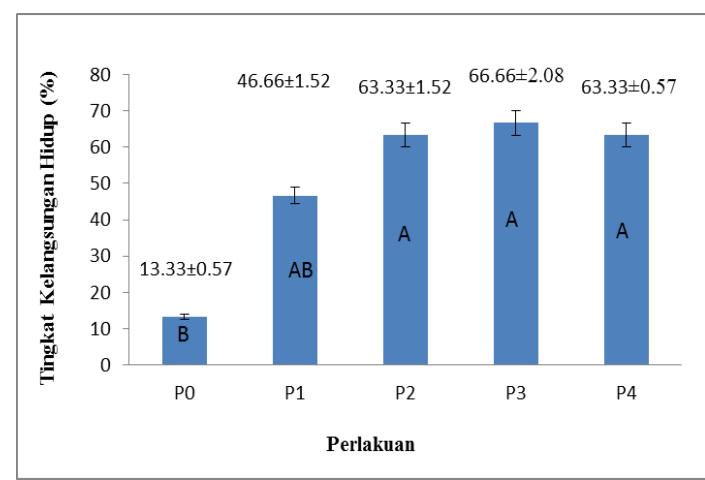

Gambar 1. Kelangsungan Hidup Ikan Nila

Berdasarkan grafik kelangsungan hidup diatas dapat diketahui bahwa kelangsungan hidup tertinggi yaitu pada perlakuan P3 yaitu $66,66 \%$ dan terendah yaitu P0 yaitu 13,33\%, yang didukung dengan hasil uji analysis of variance (ANOVA) menunjukkan bahwa perbedaan dosis perendaman ikan nila yang terinfeksi bakteri $A$. hydrophila menggunakan ekstrak biji pepaya (Carica papaya) berpengaruh nyata terhadap kelangsunan hidup ikan nila, sehingga dilakukan uji lanjut untuk mengetahui perbedaan setiap perlakuan. Berdasarkan hasil uji lanjut Tukey menunjukkan bahwa perbedaan dosis perendaman berpengaruh nyata terhadap kelangsungan hidup ikan nila.

\section{Profil Sel Darah Merah}

Pada penelitian ini dilakukan tiga kali uji sel darah merah.Uji sel darah merah pertama dilakukan pada ikan yang belum diinfeksi bakteri $A$. hydrophila, uji sel darah merah kedua setelah ikan terinfeksi dan uji sel darah merah ketiga setelah 14 hari masa pemeliharaan.Adapun uji sel darah merah yang dilakukan yaitu untuk menghitung jumlah sel darah merah dan morfologi sel darah merah.Hasil perhitungan sel darah merah dapat dilihat pada gambar 2 .

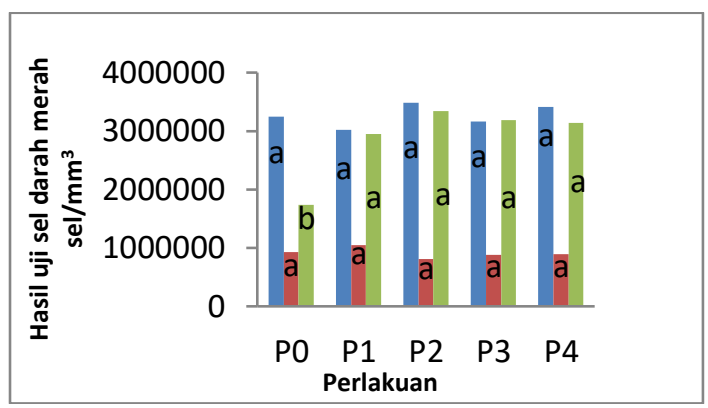

Gambar 2. Uji Sel Darah Merah Ikan Nila

Berdasarkan hasil uji analysis of variance (ANOVA) (lampiran 3) bahwa konsentrasi yang berbeda untuk perendaman ikan nila yang terinfeksi bakteri A. hydrophila menggunakan ekstrak biji pepaya (Carica papaya) berpengaruh nyata terhadap jumlah sel darah merah ikan nila, sehingga dilakukan uji lanjut untuk mengetahui perbedaan setiap perlakuan.Berdasarkan hasil uji lanjut Tukey bahwa perlakuan P0 yang tidak dilakukan perendaman dengan ekstrak biji pepaya berbedanyata dengan P1, P2, P3 dan P4 yang telah direndam atau diobati dengan ekstrak biji pepaya. Dari hasil uji sel darah merah ikan nila ini didapatkan konsentrasi tebaik untuk dipergunakan dan dapat memperbaiki kondisi sel darah merah ikan nila yang terinfeksi bakteri A. hydrophilayaitu P1 
dikarenakan $\mathrm{P} 1$ dengan $\mathrm{P} 2, \mathrm{P} 3$, dan $\mathrm{P} 4$ tidak ada perbedaan sehingga hasilnya sama.

\section{Pertumbuhan Berat Mutlak dan Panjang Mutlak}

Pertambahan panjang mutlak merupakan selisih antara panjang pada ikan antara ujung kepala hingga ujung ekor tubuh pada akhir penelitian dengan panjang tubuh pada awal penelitian, sedangkan berat mutlak merupakan selisih antara berat awal pemeliharaan dan berat akhir pemeliharaan pada penelitian ini. Adapun grafik pertumbuhan berat dan panjang mutlak ikan nila disajikan pada gambar 3 dan 4 sebagai berikut:

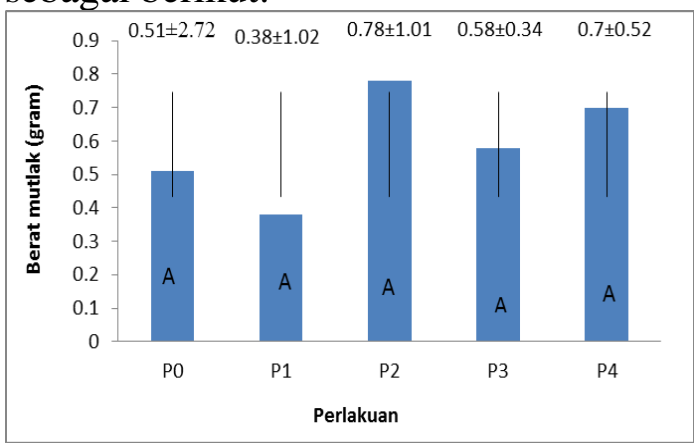

Gambar 3. Berat Mutlak pada Ikan Nila

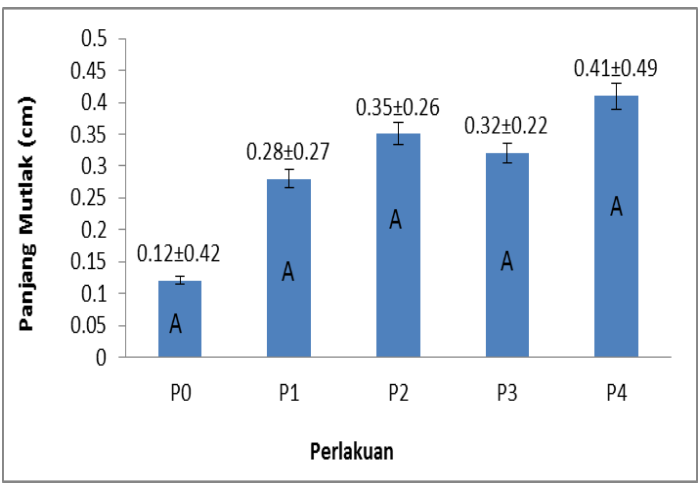

Gambar 4. Panjang Mutlak pada Ikan Nila

Hasil uji analysis of variance (ANOVA) yang telah dilakukan didapatkan hasil bahwa perendaman ikan nila dengan ekstrak biji pepaya tidak memiliki pengaruh nyata terhadap pertumbuhan panjang dan berat mutlak ikan nila.

\section{Kualitas Air}

Air merupakan habitat atau media paling penting dalam budidaya, baik buruknya kualitas air dapat mempengaruhi pertumbuhan dan kesehatan ikan serta merupakan kunci kesuksesan dalam melakukan budidaya. Pada penelitian ini dilakukan beberapa pengamatan kualitas air yaitu suhu, $\mathrm{pH}$, dan DO. Dalam penelitian ini kualitas air pada awal pemeliharaan dan akhir pemeliharaan tidak terlalu menunjukkan perbedaan yang jauh, dikarenakan pada masa pemeliharaan ikan dilakukan penyiponan air media sebanyak 1 kali dalam 2 hari. Hasil pengamatan parameter kualitas air pada penelitian ini disajikan pada table 4, 5 dan 6 .

\section{Suhu}

Suhu merupakan keadaan perairan yang mencakup panas dan dingin. Pengukuran suhu pada penelitian ini dilakukan sebanyak $2 x$ yaitu suhu awal pemeliharaan dan suhu ahir pemeliharan, dimana pemeliharaan dilakukan selama 14 hari. Hasil dari pengukuran suhu disajikan pada tabel 1 berikut:

Tabel 1. Tabel Pengukuran Suhu

\begin{tabular}{llll}
\hline Perlakuan & \multicolumn{3}{l}{ Suhu $\left({ }^{\circ} \mathbf{C}\right)$} \\
\cline { 2 - 4 } & Awa & Akhi & Litera \\
& 1 & r & tur \\
\hline P0 & $28,1-$ & $28,9-$ & $25-$ \\
& 28,9 & 29,1 & $30^{\circ} \mathrm{C}$ \\
P1 & $28,3-$ & $29,0-$ & (Aliy \\
& 29,1 & 29,4 & as \\
P2 & $28,1-$ & $29,1-$ & et al, \\
& 29,1 & 29,4 & \\
P3 & $28,4-$ & $29,0-$ & $2016)$ \\
& 28,9 & 29,3 & \\
P4 & $28,3-$ & $28,9-$ & \\
& 29,0 & 29,4 & \\
\hline
\end{tabular}

Dari tabel diatas dapat diketahui suhu awal pemeliharan pada penelitian ini berkisar antara 28,1-29,1 ${ }^{\circ} \mathrm{C}$ dan suhu ahir pemeliharaan yaitu berkisar antara $28,9-29,4^{\circ} \mathrm{C}$. 


\section{Derajat Keasaman (pH)}

Derajat keasaman air merupakan gambaran air tersebut apakah asam atau basa. $\mathrm{pH}$ netral yaitu 7 sedangkan $\mathrm{pH}$ asam yaitu $\mathrm{pH}<7$ dan $\mathrm{pH}$ basa yaitu $\mathrm{pH}>7$. Pengukuran $\mathrm{pH}$ pada penelitian ini disajikan dalam tabel 2 berikut ini:

Tabel 2. Table Pengukuran $\mathrm{pH}$

\begin{tabular}{lllll}
\hline \multirow{2}{*}{$\begin{array}{l}\text { Perlakua } \\
\text { Perajat Keasaman }(\mathbf{p H})\end{array}$} & \multicolumn{4}{l}{ Derajary } \\
\cline { 2 - 5 } & Awa & Akhi & Literatur \\
& 1 & r & & \\
\hline P0 & $7,1-$ & $8,4-$ & $6,5-9$ & \\
& 7,3 & 8,7 & & \\
P1 & 7,5 & $8,4-$ & (Maisyaro \\
& & 8,7 & h & \\
P2 & $7,1-$ & $8,3-$ & et & al, \\
& 7,5 & 8,5 & $2018)$ & \\
P3 & $7,2-$ & $8,4-$ & & \\
& 7,5 & 8,5 & & \\
P4 & $7,3-$ & $8,3-$ & & \\
& 7,5 & 8,8 & & \\
\hline
\end{tabular}

Dari hasil penelitian ini didapatkan rata-rata $\mathrm{pH}$ awal yaitu 7,17,5 sedangkan $\mathrm{pH}$ akhir yaitu 8,3-8,8, hasil tersebut masih diambang batas optimal untuk pertumbuhan ikan nila.

\section{Oksigen Terlarut (DO)}

Oksigen merupakan salah satu faktor pembatas yang apabila ketersediaannya didalam perairan tidak mencukupi biota budidaya, maka akanmempengaruhi segala aktivitas biota budidaya tersebut. Nilai oksigen terlarut dari penelitian ini disajikan dalam tabel 3 berikut:

Tabel 3. Tabel Pengukuran Oksigen Terlarut (DO)

\begin{tabular}{llll}
\hline Perlakuan & \multicolumn{3}{c}{ Oksigen Terlarut (DO) } \\
\cline { 2 - 4 } & Awal & Akhir & Literatur \\
\hline P0 & $7,3-$ & $6,9-$ & $5-7 \mathrm{mg} / 1$ \\
& 7,5 & 7,4 & \\
P1 & $7,2-$ & $6,6-$ & (Bahnan, \\
& 7,4 & 7,2 & $2018)$ \\
P2 & $7,2-$ & $6,5-$ & \\
& 7,4 & 7,3 & \\
\hline
\end{tabular}

\begin{tabular}{lll}
\hline P3 & $7,3-$ & $6,7-$ \\
& 7,6 & 6,8 \\
P4 & $7,3-$ & $6,5-$ \\
& 7,7 & 7,4 \\
\hline
\end{tabular}

Dari hasil penelitian didapatkan hasil rata-rata pengukuran awal yaitu berkisar antara 7,2-7,7 sedangkan pada akhir pemeliharaan yaitu 6,5-7,4

\section{PEMBAHASAN}

\section{Tingkat Kelangsungan Hidup Ikan Nila}

Persentase kelangsungan hidup perlakuan $\mathrm{P} 0$ dengan $\mathrm{P} 1$ menunjukkan hasil yang tidak berbeda nyata, namun P0 menunjukkan hasil berbeda nyata dengan P2, P3 dan P4 sedangkan P2, P3 dan $\mathrm{P} 4$ tidak berbeda nyata. Dari hasil uji analysis of variance (ANOVA) dan dilakukan uji lanjut Tukey konsentrasi P2 merupakan konsentrasi yang dapat disarankan untuk dipergunakan pada pengobatan ikan nila yang terinfeksi bakteri A. hydrophila dikarenakan konsentrasi P2 berbeda nyata dengan P1 dan P0 namun tidak berbeda nyata dengan P3 dan P4, hal ini dapat dikarenakan pada P2,P3 dan P4 senyawa terpenoid, karpain dan flavonoid berfungsi dengan baik membunuh bakteri $A$. hydrophila yang bekerja dengan caramerusak integritas membran sel bakteri. Penelitian sebelumnya yang telah dilakukan oleh Jaipah et al. (2017) tentang uji efektivitas antibakteri biji pepaya terhadap pertumbuhan bakteri Escherichia coli secara in vitro menunjukkan bahwa semakin besar konsentrasi ekstrak maka semakn besar daya hambat.

Senyawa terpenoid, karpain, dan flavonoid didapatkan dari hasil ekstraksi biji pepaya menggunakan etanol $90 \%$ dengan metode maserasi, dimana etanol bersifat polar dan kandungan tepenoid, karpain, dan flavonoid yang ada pada biji pepaya juga bersifat polar, sehingga etanol dapat mengikat ketigasenyawa 
yang berperan sebgai anti bakteri pada biji pepaya tersebut. Hal ini diperkuat oleh pendapat Maryam (2017) bahwa etanol merupakan pelarut terbaik untuk memperoleh ekstrak kasar senyawa antibakteri flavonoid, karpain dan terpenoid yang bersifat polar.

\section{Profil Sel Darah Merah}

Uji darah merah menunjukkan darah ikan sehat rata-rata diatas $30 \times 10^{5}$ $\mathrm{sel} / \mathrm{mm}^{3}$ sedangkan ikan sakit ikan yang telah diinfeksi bakteri $A$. hydrophila menunjukka rata-rata diatas $5 \times 10^{5}$ $\mathrm{sel} / \mathrm{mm}^{3}$ dan ikan pada perlakuan $\mathrm{P} 1$, P2, P3, dan P4 yang telah direndam menggunakan ekstrak biji pepaya dan di pelihara selama 14 hari menujukkan hasil uji darah diatas $25 \times 10^{5} \mathrm{sel} / \mathrm{mm}^{3}$ sedangkan ikan yang tidak direndam menunjukkan hasil perhitungan yaitu $17,4 \times 10^{5} \mathrm{sel} / \mathrm{mm}^{3}$. Hasil uji darah tersebut diketahui bahwa darah ikan menunjukkan hasil yang normal, hal ini sesuai dengan pendapat Hartika (2014) bahwa jumlah eritrosit ikan nila pada umumnya yaitu 20.000$3.000 .000 \mathrm{sel} / \mathrm{mm}^{3}$, namun terdapat perbedaan untuk jumlah eritrosit pada ikan sehat dan ikan sakit, hal ini diduga karna adanya perbedaan daya tahan tubuh ikan yang sehat dan ikan yang sakit, sehingga jumlah eritrosit pada ikan yang sakit terutama ikan yang terserang bakteri jauh lebih rendah dibandingkan ikan yang sehat. Angka (1990) dalam Minaka (2012) menjelaskan bahwa proses pecahnya sel darah merah dikarenakan bakteri menghasilkan toxin yang salah satu fungsi enzim tersebut adalah menghasilkan enzim haemolisin yang bertugas untuk melisiskan sel darah merah. Tingginya eritrosit atau sel darah merah di atas rata-rata pada ikan dapat dikarenakan ikan mengalami setres pada saat pengambilan darah. Menurut Kurniawan (2019) keadaan stres mampu memberi dampak buruk bagi ikan, stres memepengaruhi kinerja dan kesehatan ikan berupa gangguan fungsi sel darah salah satunya yaitu eritrosit, untuk mengurangi keadaan stres maka ikan akan menyesuaikan kondisi fisiologisnya dengan meningkatkan jumlah eritrosit dalam sirkulasi.

Hasil pengamatan morfolgi sel darah merah ikan menunjukkan adanya perbedaan antara ikan sehat dan sakit. Perbedaan tersebut ditunjukkan pada gambar berikut ini

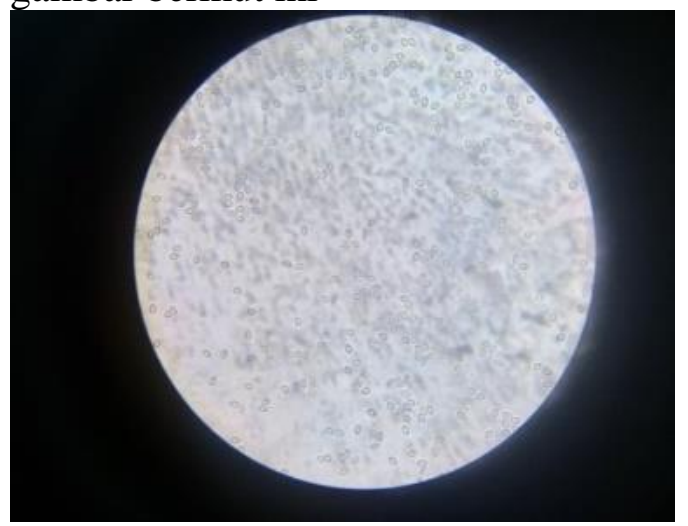

Gambar 5.Gambar Sel Darah IkanSehat

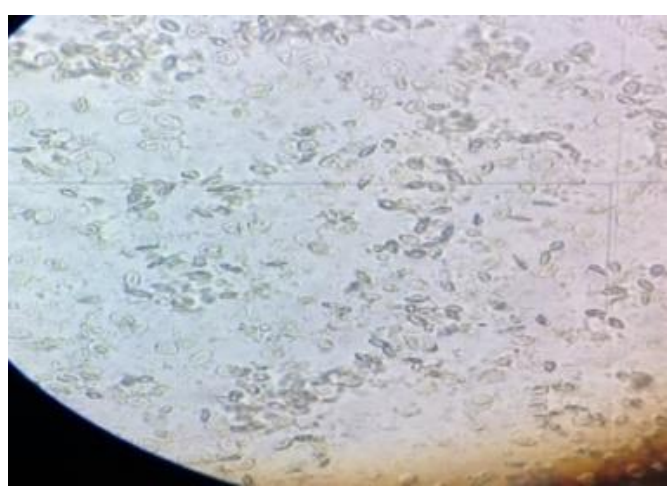

Gambar 6.Sel Darah Ikan Sakit

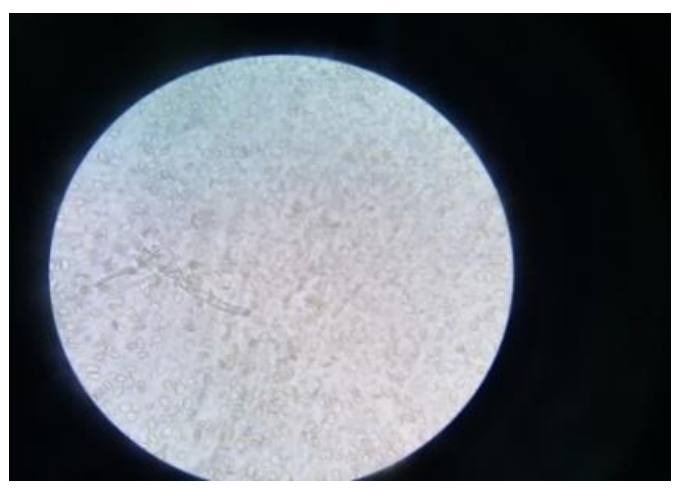

Gambar7. Sel Darah Ikan Pasca Pengobatan 
Dari gambar 5 dan 6 dapat dilihat perbedaan gambaran darah dimana darah pada ikan sehat sel eritrosit kondisi eritrosit normal atau dewasa dengan bentuk eritrosit bulat, inti sel bulat sedangkan pada gambar 6 sel eritrosit sedikit tidak beraturan atau pecah dan dilihat dalam mikroskop jumlah eritrosit pada ikan sakit lebih sedikit dikarenakan ikan terinfeksi bakteri. Gambar 7 menunjukkan sel eritrosit mulai meningkat pasca pengobatan menggunakan ekstrak biji pepaya dan sel eritrosit mengalami perbaikan dari eritrosit yang pecah menjadi eritrosit muda yang selnya mulai tampak utuh dan bulat.Mastuti (2017) menyatakan bahwa eritrosit dewasaberbentuk bulat telur dengan inti bulat telur dan sitoplasma merah muda, sedangkan eritrosit ikan yang terinfeksi A. hydrophila mengalami perubahan morfologi dan anatomi, eritrosit mengalami haemolisis atau pecahnya membran sel sehingga menyebabkan bentuk inti selnya tidak beraturan.

\section{Pertumbuhan Berat Mutlak dan Panjang Mutlak}

Hasil uji analysis of variance (ANOVA) yang telah dilakukan didapatkan hasil bahwa perendaman ikan nila dengan ekstrak biji pepaya tidak memiliki pengaruh nyata terhadap pertumbuhan panjang dan berat mutlak ikan nila. Hal ini dapat dikarenakan bahwa ikan masih dalam proses penyembuhan sehingga nafsu makan ikan masih berkurang, hal ini dapat dilihat dari banyaknya sisa pakan yang berada diwadah pemeliharaan. Hal ini sesuai dengan pernyataan Ristianti (2015), lemahnya respon ikan terhadap pakan disebabkan oleh terganggunya sistem pencernaan ikan akibat adanya infeksi bakteri $A$. hydrophila yang menyerang bagian hipotalamus (otak) sebagai pusat yang mengatur rasa lapar dan juga pencernaan ikan, sehingga ikan lambat untuk mencerna pakan

\section{Kualitas Air \\ Suhu}

Kisaran suhu yg didapatkan pada penelitian ini berkisar antara 28,1-29,1 ${ }^{\circ} \mathrm{C}$ dan suhu akhir pemeliharaan yaitu berkisar antara $28,9-29,4^{\circ} \mathrm{C}$ termasuk optimal untuk pertumbuhan ikan nila. Menurut Aliyas et al ,(2016) menyatakan bahwa suhu optimal untuk pertumbuhan ikan nila yaitu $25-30^{\circ} \mathrm{C}$. Tinggi rendahnya suhu dapat mempengaruhi proses pencernaan makanan pada ikan dan juga aktivitas lainnya selain itu suhu juga sangat berkaitan erat dengan konsentrasi oksigen terlarut.

\section{Derajat Keasaman (pH)}

Dari hasil penelitian ini didapatkan rata-rata $\mathrm{pH}$ awal yaitu 7,17,5 sedangkan $\mathrm{pH}$ akhir yaitu 8,3-8,8, hasil tersebut masih diambang batas optimal untuk pertumbuhan ikan nila. Hal ini sesuai dengan pernyataan Maysyaroh (2018) yang menyatakan bahwa $\mathrm{pH}$ optimal untuk pertumbuhan ikan nila yaitu 6,5-9.

\section{Oksigen Terlarut (DO)}

Oksigen terlarut merupakan faktor penting penunjang budidaya. Dari hasil penelitian didapatkan hasil rata-rata pengukuran awal yaitu berkisar antara 7,2-7,7 sedangkan pada akhir pemeliharaan yaitu 6,5-7,4. Dari hasil pengamatan tersebut dapat diketahui bahwa kondisi atau nilai kadar konsentrasi oksigen terlarut (DO) pada media pemeliharan ikan saat penelitian dapat dikategorikan normal untuk kehidupan ikan nila. Hal ini diperkuat oleh Bahnan (2018) yang menyatakan bahwa konsentrasi minimum yang dapat diterima sebagian besar biota budidaya untuk hidup yaitu 5-7mg/l. 


\section{KESIMPULAN}

Berdasarkan hasil penelitian ini didapatkan kesimpulan sebagai berikut: Penggunaan ekstrak biji pepaya terhadap kelangsungan hidup ikan nila berpengaruh nyata, dimana perlakuan yang direkomendasikan adalah perlakuan P2 dengan dosis $30 \%$.

Pemberian ekstrak biji pepaya berpengaruh nyata terhadap jumlah sel darah merah ikan nila. Perlakuan terbaik atau perlakuan yang dapat direkomendasikan yaitu P1 dengan dosis $20 \%$.

Dosis perendaman ikan nila yang terinfeksi bakteri A. hydrophila menggunakan ekstrak biji pepaya tidak berpengaruh nyata terhadap pertumbuhan panjang mutlak dan berat mutlak ikan nila.

\section{DAFTAR PUSTAKA}

Alamanda, I. E., Handajani, N. S., dan Budiharjo, A. (2007). Penggunaan Metode Hematologi dan Pengamatan Endoparasit Darah dan Penetapan Kesehatan Ikan Lele Dumbo (Clarias gariepinus) di Kolam Budidaya Desa Mangkubumen Boyolali. Jurnal Biodiversitas, 8(1), 34-38.

Aliyas, Ndobe, S., dan Ya'la, Z. R. (2016). Pertumbuhan dan Kelangsungan Hidup Ikan Nila (Oreochromis sp.) yang di Pelirhara pada Media Bersalinitas. Jurnal Sains dan Teknologi Tadulako, 5(1), 19-27.

Arifin, M. Y. (2016). Pertumbuhan dan Survival Rate Ikan Nila (Oreochromis sp.) Strain Merah dan Strain Hitam yang Dipelihara pada Media Bersalinitas. Jurnal Ilmiah Universitas Batanghari Jambi, 16(1).

Arwin, M., Ijong, F. G., dan Tumbol, R. (2016). Karakteristik Aeromonas Hydrophila yang Diisolasi dari Ikan Nila (Aeromonas hydrophila). Fakultas Perikanan dan Ilmu Kelautan UNSRAT.

Bahnan, M. (2018). Strategi Pengendalian Penyakit Parasit dan Bakteri pada Budidaya Ikan Nila (Aeromonas hydrophila) di KJA DAS Batanghari (Studi kasus Desa Pematang Jering Kabupaten Muaro Jambi). [Tugas Akhir Program Megister]. Ilmu Kelautan Manajemen Perikanan Universitas Terbuka.

Haryani, A., Grandiosa, R., Buwono, I, D., dan Santika, A. (2012). Uji Efektivitas Daun Pepaya (Carica papaya) untuk Pengobatan Infeksi Bakteri Aeromonas hydrophila Pada Ikan Mas Koki (Carassius auratus). Jurnal Perikanan dan Kelautan, 3(3), 213-220.

Insivitawati, E., Mahasri, G., dan Kusnoto. (2015). Gambaran Darah dan Histopatologi Insang, Usus dan Otak Ikan Koi (Cyprinus carpio koi) yang Diinfeksi Spora Myxobolus Koi Secara Oral. Jurnal Ilmiah Prikanan dan Kelautan,7(2).

Jaipah, N., Saraswati, I., dan Hapsari, R. (2017). Uji Efektivitas Antimikroba Ekstrak Biji Pepaya (Carica papaya L.) Terhadap Pertumbuhan Accherichia Coli Secara In Vitro. Jurnal Kedokteran Diponegoro, 6 (2).

Jasmanindar, Y. (2011). Prevalensi Parasit dan Penyakit Ikan Air Tawar yang Dibudidayakan Di Kota/Kabupaten Kupang. Jurnal Ilmu-ilmu Hayati dan Fisik, 13 (1), 25-30.

Kurniawan, A.P. Suminto, Condro, H. (2019). Pengaruh Penambahan Bakteri Kandidat Probiotik Bacillus methylothropicus pada Pakan Buatan Terhadap Profil Dadar dan Performa Pertumbuhan Ikan Nila (Oreochromis niloticus) yang Duji Tantang dengan Bakteri 
Aeromonas hydrophila. Jurnal Sains Akuakultur Tropis, 3(1), 82-92.

Lasena, A., Nasriani., dan Irdja, A. M. (2016). Pengaruh Dosis Pakan yang Dicampur Probiotik Terhadap Pertumbuhan dan Kelangsungan Hidup Benih Ikan Nila (Aeromonas hydrophila). Program Studi Budidaya Perairan Universitas Muhammadiyah Gorontalo.

Lukman, Mulyana, dan Mumpuni, F. S. (2014). Efektivitas Pemberian Akar Tuba (Derris elliptica) Terhadap Lama Waktu Kematian Ikan Nila (Oreochromis niloticus). Jurnal Pertanian, 5(1), 22-31. Fakultas Pertanian Universitas Djuanda Bogor.

Maesaroh. (2013). Analisis Filogenetik Isolat Bakteri Aeromonas Hydropilla dari Ikan sehat. Universitas Pendidikan Indonesia. Perpustakaan.upi.edu

Maisyaroh, L. A.Titis S., AH Condro H, Fajar. B, T. Yuniarti. (2018). Penggunaan Ekstrak Kulit Buah Manggis (Garcinia mangostana) sebagi Antibakteri nntuk Mengobati Infeksi Aeromonas hydrophila pada Ikan Nila (Oreochromis niloticus). Jurnal Sains Akuakultur Tropis, 2(2), 36-43.

Maryam, S. (2017). Isolasi Senyawa Flavonoid dari Biji Pepaya dan Uji Aktivitasnya sebagai Anti Bakteri. [Skripsi]. Fakultas Matematika dan Ilmu pengetahuan Alam Universitas Negeri Semarang.

Mastuti, R. (2017). Pengobatan Penyakit MAS (Motile aeromonas septicaemia) dengan Ekstrak Daun Mangrove (Rizophora sp.) pada Ikan Jambal Siam (Pangasius hypophthalmus). [Skripsi]. Pekanbaru: Fakultas
Perikanan dan Kelautan Universitas Riau.

Mulqan, M. (2017) .Pertumbuhan dan Kelangsungan Hidup Benih Ikan Nila Gesit (Oreochromis niloticus) Pada Sistem Akuaponik Dengan Jenis Tanaman Yang Berbeda. Jurnal Ilmiah Mahasiswa Kelautan dan Perikanan Unsyiah, 2(1), 183193.

Mulyono, L. M. (2013). Efektivitas Antibakteri Ekstrak Etanol Biji Buah Pepaya (Carica papaya L.) Terhadap Escherichia coli dan Staphylococcus aureus. Jurnal Ilmiah Mahasiswa Universitas Surabaya, 2(2).

Muslikha, Pujianto, S., Jannah, S, N., Novita,H. (2016). Isolasi, Karakterisasi Aeromonas Hydrophila dan Deteksi Gen Penyebab Penyakit Motile Aeromonas Septicaemia (MAS) dengan 16S rNA dan Aerolysin pada Ikan Lele (Clarias sp.) Jurnal Biologi, 5(4), 1-7.

Paramesti, N. N. (2014). Efektivitas Ekstrak Biji Pepaya (Carica papaya L.) Sebagai Anti Bakteri Terhadap Bakteri Escherichia coli. [Skripsi]. Program Studi Pendidikan Dokter Fakultas Kedokteran dan Ilmu Kesehatan Universitas Islam Negeri Syarif Hidayatullah.

Rinawatiasih. (2012). Pemberian Ektrak Biji Pepaya (Carica papaya) Pada Ikan Mas (Cyprinus carpio L.) yang Terinfeksi Bakteri Aeromonas hydrophila. Universitas Muhammadiyah Purwokerto.

Ristianti, D. I., Rustikawati, I., dan Lili, W. (2015). Efektivitas Ekstrak Biji Pepaya Mentah (Carica papaya L.) dalam Pengobatan Banih Ikan Nila yang Terinfeksi Bakteri Strptococcus agalactiae. 
Jurnal Perikanan (2021) Volume 11. No. 28-40

DOI : https://doi.org/10.29303/jp.v10i2.198

Jurnal Perikanan Kelautan, 6(2), 23-31.

Sari, D. S. (2012). Pencegahan Infeksi Aeromonas hydrophila pada Ikan Nila (Oreochromis niloticus) dengan Pemberian Ekstrak Etil Asetat Rimpang Temu Ireng (Curcuma aeroginosa). [Skripsi]. Jurusan Biologi Fakultas Matematika dan Ilmu Pengetahuan Alam Universitas Sebelas Maret.

Sari, T. P. E., Gunaedi, T., dan Indrayani, E. (2017). Pengendalian Infeksi Bakteri Aeromonas Hydrophila pada Ikan Nila (Oreochromis niloticus) dengan Ekstrak Rimpang Merah (Alpinia purpurata). Jurnal Biologi Papua, 9(2), 37- 42. 